\title{
Interleukin-6 as Immune System and Inflammation Biomarker on the Response of Basic Pencak Silat Exercise in Perguruan Pencak Silat Perisai Diri, Bojonegoro
}

\author{
Roy $\operatorname{Irawan}^{1} \mathbb{D}$, Trias Mahmudiono $^{2 *}(\mathbb{D})$ Tri Martiana $^{3}$ \\ ${ }^{1}$ Department of Sport Science, Faculty of Sport Science, Universitas Negeri Surabaya, Surabaya, East Java, Indonesia; \\ ${ }^{2}$ Department of Nutrition, Faculty of Public Health, Universitas Airlangga, Surabaya, East Java, Indonesia; ${ }^{3}$ Departement of \\ Occupational Safety and Health, Faculty of Public Health, Universitas Airlangga, Surabaya, East Java, Indonesia
}

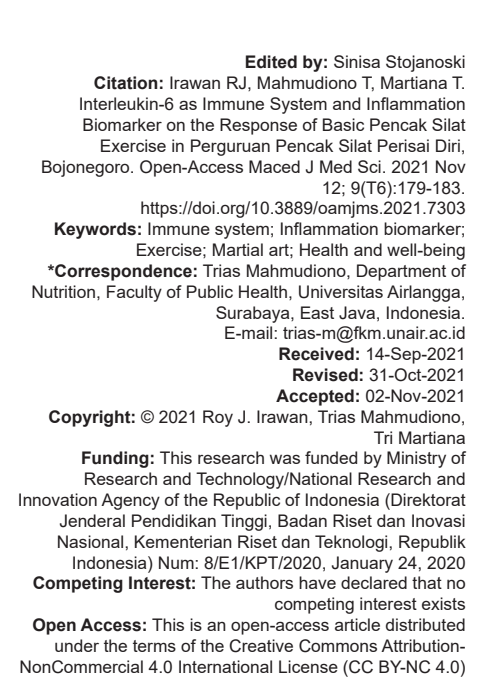

\section{Abstract}

BACKGROUND: Pencak Silat is a self-defense exercise originated from Indonesia and categorized as a highintensity exercise.

AIM: This research was intended to identify the acute response of Pencak Silat basic exercise toward interleukin- 6 (IL-6) as an immune system biomarker on students of Perguruan Pencak Silat Perisai Diri Tulungrejo, Bojonegoro.

METHODS: A number of 26 students (10 boys and 16 girls) of Perguruan Pencak Silat Tulungrejo, Bojonegoro, were participated in this study. The students did the $2 \mathrm{~h}$ Perguruan Pencak Silat Perisai Diri, Bojonegoro, training program with $75-85 \%$ intensity. The IL-6 serum was measured using ELISA method.

RESULTS: The result of this study showed that the IL-6 serum level in post-2 (12 h after training) $(6.2981 \mathrm{pg} / \mathrm{mL})$ was higher compared with the IL-6 serum level in post-1 (shortly after training) $(6.11981 \mathrm{pg} / \mathrm{mL}$ ) and before training $(4.5146 \mathrm{pg} / \mathrm{mL})$. The result also showed that there was a significant difference of IL-6 levels between pre-training and after training.

CONCLUSION: This study concluded that the basic exercise performed by the new students of Perguruan Pencak Silat Perisai Diri increased IL-6 serum level.

\section{Introduction}

Previous theory showed that there are changes in body's immune system due to acute exercise that occurs between 3 until $72 \mathrm{~h}$ after exercise, although it depends on the parameters measured [1]. The previous study also showed that there was a risk in diseases transmission after doing high-intensity physical activity [2]. This is due to the depression of body immune system that occurs after high-intensity exercise as explained in J-curve theory, in which the moderate-intensity level of physical activity could increase body immune system, while, in contrast, prolonged high-intensity level of physical activity could alter body immune function [3]. Exhausting physical activity could lead to exaggerated inflammatory reaction that causes immunity suppression, therefore causing clinical consequence that slowdown the healing and recovery of injury and increasing disease or infection risk [4].
Inflammation is a complex event that involves lots type of cells and molecules that are called proinflammatory cytokines. These cytokines are the earliest product as a response toward stress and they have important role as an innate and adaptive immune system. They have function as signal between cells that control local and systemic response. Cytokines can be induced and divided into two different families, the proinflammatory cytokines (interleukin [IL]-1 $\beta$, IL-2, IL-4, IL-6, IL-8, and tumor necrosis factor-alpha [TNF- $\alpha]$ ) that have function to increase systemic inflammation and inflammatory cytokines (IL-5, IL-6, and IL-10) that have protective and reducing character toward inflammation. Exaggerated inflammation may cause harm and excessive production of IL- $1 \beta$, while TNF- $\alpha$ may cause pathological problems [5].

Cytokines is a small protein $(<40 \mathrm{kDa})$ secreted and produced by almost all cells in the body to control and influence immune response. Releasing pro-inflammatory cytokines will trigger the activation 
and production of immune cells and release further cytokines. Therefore, the "cytokines storm" term is explaining inflammation as the proses of sudden cytokines release to increase inflammatory process. IL-6 is rapidly produced and acted as temporary response toward infection and tissue injury and has contribution in body's immune system by stimulating acute-phase response, hematopoiesis, and immune reaction [6].

A previous study reported that there were increments in IL-6 plasma concentration as a response toward physical exercise performed by an individual. Exercise and strenuous exercise will induce the level of several pro- and anti-inflammation cytokines inhibit natural cytokines and chemokines. IL-6 level will increase 100-fold after running marathon race. Higher increment of IL-6 level will be produced as the response toward exercise compared with the other cytokines type. IL-6 is produced locally in skeletal muscle as a response toward exercise, and it is known that IL-6 induces the output of hepatic glucose and inducing lipolysis [7]. Strenuous endurance exercise will cause leukocytosis that occurs due to neutrophilia in circulation, damaging muscle and internal organs, and suppressing immunity. To determine the cause of this phenomenon, attention should be focused on cytokines that are released to the circulation system. A lot of research showed consistent finding that IL-1ra, IL-6, IL-8, and IL-10 have significant increase in prolonged endurance exercise that takes place in longer hours, such as marathon and triathlon [8]. High Mobility Group Box 1 (HMGB 1) is pro-inflammatory cytokines that have important role in sterilized inflammation, infection, until sepsis. Intracellular response will be activated by the binding between HMGB1 and the surface of immune cell that aims to control the function of immunity cells, including chemotaxis and modulation of immune system [9]. There will be increase in systemic HMGB1 after doing aerobic exercise with high intensity, treadmill, marathon run, and 5 min step test in hypoxic room [10].

Endurance exercise is also applied in Pencak Silat. Pencak Silat is a self-defense exercise originated from Indonesia. Basic moves in Pencak Silat consist of punching, kicking, step patterns, defense, and cutting style (guntingan). Like the other physical exercise, Pencak Silat also implements principal exercises that aim to improve physical condition. In Pencak Silat course, new students have to undergo basic exercise, the first exercise from them to adapt before they will be given with the next level of exercise. Basic exercise in Perguruan Pencak Silat Tulungrejo, Bojonegoro, consists of warming up, core exercise, and cooling down, which last for 90-120 min per exercise session. The basic exercise activity of Perisai Diri is dominated by eccentric move such as kicking and punching, also jumping and running. However, the response of immune system toward basic exercise in Perguruan Pencak Silat Perisai Diri has not been thoroughly studied. Therefore, this research was intended to identify the acute response of Pencak Silat basic exercise toward IL-6 as immune system biomarker in students of Perguruan Pencak Silat Perisai Diri Tulungrejo, Bojonegoro.

\section{Materials and Methods}

A number of 26 students (10 boys and 16 girls) of Perguruan Pencak Silat Tulungrejo, Bojonegoro, aged 17 years old, body weight $61 \mathrm{~kg}$, and in healthy condition were participated in this study. This study protocol was already approved by the local ethical committee Komite Etik Penelitian Kesehatan Masyarakat, Universitas Airlangga and all participants had been given information on the risk and the objective of this study before they filled the informed consent. Pencak Silat exercise was done in Perguruan Pencak Silat Tulungrejo, Bojonegoro, East Java, Indonesia. The exercise was using basic exercise method from the Perguruan Perisai Diri with 120 min duration, consisting of warming up, core exercise, and cooling down.

Blood samples were taken from intercubital blood vessel before (pre) the basic exercise. After that, blood samples were taken shortly after (post1) and $12 \mathrm{~h}$ after the exercise (post-2). The study subjects had not been doing exercise activities in the previous 2 days. The subjects were also allowed to consume any food they wanted, but prohibited from taking supplement and drugs 1 week before the intervention and data collection of data. Blood sample was taken from cubitus vein as much as $5 \mathrm{cc}$ then added with EDTA. Centrifugation process was held in $15 \mathrm{~min}$ and in $3000 \mathrm{rpm}$, then, the blood plasma was saved in a freezer in $20^{\circ} \mathrm{C}$ temperature. The $100 \mu \mathrm{L}$ of plasma before (pre), shortly after (post-1), and $12 \mathrm{~h}$ after intervention (post-2) were used to count the IL-6 level. To check the IL-6 level, we used Kit Human IL-6 using double antibody sandwich ELISA method.

The collected data were processed manually and digitally to change the data to information. Data analysis used in this study was univariable analysis to portray the subject characteristic. The normality test is used was the Kolmogorov-Smirnov test. Bivariate analysis was also used to compare the difference between IL-6 level before (pre), shortly after (post-1), and $12 \mathrm{~h}$ after intervention (post-2). Mann-Whitney U-test was used if the data were not normally distributed and independent-t test was used if the data were normally distributed. This study was conducted on September 2020 until January 2021 in Public Health Faculty, Universitas Airlangga, Surabaya, Indonesia. 


\section{Results and Discussion}

\section{Respondents' characteristics}

A number of 26 students, consisting of 10 boys and 16 girls, with mean age 16 years old (SD \pm 0.9 ) were students of Perguruan Pencak Silat Tulungrejo, Bojonegoro, and willing to become respondents and participate in this study. Other characteristics of the respondents are shown in Table 1.

Table 1: Respondents' characteristics

\begin{tabular}{llllll}
\hline Variable & $\mathrm{n}$ & Minimum & Maximum & Mean & SD \\
\hline Age & 26 & 16.00 & 19.00 & 26.7308 & 0.91903 \\
Weight & 26 & 43.6 & 77.40 & 60.4000 & 9.53138 \\
Height & 26 & 147.00 & 177.00 & 162.077 & 7.47138 \\
Valid $\mathrm{n}$ & 26 & & & & \\
\hline
\end{tabular}

\section{Normality and homogeneity test}

Before doing the statistical analysis of $\mathrm{IL}-6$ serum level, data distribution normality test was done for the data of IL-6 level on pre (before), post-1 (shortly after), and post-2 (12 h) after intervention. These variables were tested using Kolmogorov-Smirnov normality test. The result of the statistical test showed that pre-intervention IL-6 serum level had $p=0.200$ with the Z-score of 0.130 , while the p-value and Z-score of post-1 and post-2 were 0.200 and 0.119 , respectively (Table 2 ). From the result, it showed that the data were normally distributed because the $p$-value was bigger higher than $\alpha=0.05$.

Table 2: Data distribution of IL-6 serum level

\begin{tabular}{llll}
\hline IL-6 serum level & $\mathrm{n}$ & $\mathrm{Z}$ & $\mathrm{p}$ \\
\hline Pre & 26 & 0.130 & 0.200 \\
Post-1 & 26 & 0.119 & 0.200 \\
Post-2 & 26 & 0.119 & 0.200 \\
\hline IL-6: Interleukin-6, *one-sample Kolmogorov-Smirnov test. & &
\end{tabular}

According to the homogeneity test using F-Levene test, the $p$-value of the three variables was $p \leq 0.001$. Therefore, we can conclude that the variety of the variables was different with degree of error $5 \%$ and these variables were heterogeneous (Table 3 ).

Table 3: Homogeneity of IL-6 serum level between pre, post-1, and post-2

\begin{tabular}{llllll}
\hline IL-6 serum level & $\mathrm{n}$ & Mean $(\mathrm{pg} / \mathrm{mL})$ & $\mathrm{SB}$ & Variation coefficient $(\%)$ & $\mathrm{p}$ \\
\hline Pre & 26 & 4.5146 & 0.211161 & 4.68 & $\leq 0.001$ \\
Post-1 & 26 & 6.11981 & 0.64657 & 10.57 & \\
Post-2 & 26 & 6.2981 & 0.64657 & 10.57 & \\
\hline IL-6: Interleukin-6. & & & & &
\end{tabular}

The IL-6 serum level in post-2 $(6.2981 \mathrm{pg} / \mathrm{mL})$ was higher compared with the IL-6 serum level in post-1 $(6.11981 \mathrm{pg} / \mathrm{mL})$ and pre $(4.5146 \mathrm{pg} / \mathrm{mL})$. The result also showed that there was a significant difference between the variables using the $95 \%$ confident intervals (Table 3 ).

\section{Comparative test using t-test}

The result from analysis using t-test with $95 \%$ confident interval showed that there was a difference in
IL-6 serum level between pre- and post-1. IL-6 serum level of pre- and post-2 also showed similar result (Table 4).

\section{Table 4: Result of t-test}

\begin{tabular}{|c|c|c|c|c|c|c|c|c|}
\hline \multirow[t]{3}{*}{ Parameters } & \multicolumn{5}{|c|}{ Paired differences } & \multirow[t]{3}{*}{$\mathrm{t}$} & \multirow[t]{3}{*}{$\mathrm{df}$} & \multirow{3}{*}{$\begin{array}{l}\text { Sig. (two } \\
\text { tailed) }\end{array}$} \\
\hline & \multirow[t]{2}{*}{ Mean } & \multirow{2}{*}{$\begin{array}{l}\text { Std. } \\
\text { deviation }\end{array}$} & \multirow{2}{*}{$\begin{array}{l}\text { Std. error } \\
\text { mean }\end{array}$} & \multicolumn{2}{|l|}{$95 \% \mathrm{Cl}$} & & & \\
\hline & & & & Lower & Upper & & & \\
\hline $\begin{array}{l}\text { Pair 1 } \\
\text { Pre-post-1 }\end{array}$ & -1.683 & 0.734 & 0.144 & -1.979 & -1.388 & -11.717 & 25 & $<0.001$ \\
\hline $\begin{array}{l}\text { Pair } 2 \\
\text { Pre-post-2 }\end{array}$ & -1.783 & 0.734 & 0.144 & -2.079 & -1.488 & -12.413 & 25 & $<0.001$ \\
\hline
\end{tabular}

The result of comparative test using t-test between pre- and post-1 had significant result ( $p \leq 0.001$ ). This showed that there was a significant difference between IL-6 serum level in pre- and post-1. Along with the result, comparative test of pre- and post-2 also showed similar result that there was significant difference between IL- 6 serum level in pre- and post-2 $(p \leq 0.001)$.

Perguruan Pencak Silat Perisai Diri Tulungrejo located in Bojonegoro is one of the self-defense courses in Indonesia. This course had exercise program aimed to increase the physical ability and condition. One of the exercise programs given to the student is the basic exercise program. This program is given so that the student will be ready and able to adapt before receiving the next level exercise. The moves in the basic exercise are varied, consisting of sprint, jogging, jumping, punching, kicking, and sweeping (Sapuan). This basic exercise is categorized as high-intensity interval training (HIIT). Exercise in this category could cause suppression in many aspects of the body immunity function, such as the increase of neutrophil, lymphocyte proliferation, and the presentation of monocyte antigen. This study aims to identify the acute response of Pencak Silat Perisai Diri basic exercise toward IL-6 as the biomarker of immune system on among the students of Perguruan Pencak Silat Perisai Diri Tulungrejo, Bojonegoro.

The results showed that there was difference in IL-6 serum level before the intervention, shortly after the intervention, and $12 \mathrm{~h}$ after the intervention. This showed that the intervention (the basic exercise of Pencak Silat) could increase IL-6 serum $1.60521 \mathrm{pg} / \mathrm{mL}$ (35.56\%) shortly after the intervention and 1.7835 (39.51\%) after $12 \mathrm{~h}$ of the intervention. Prolonged strenuous exercise could cause temporary depression in many aspects of immune function that will occur 3-24 h after the exercise. Immune system dysfunction may occur after exercising (post-exercise), especially in prolonged exercise (1.5 h) with moderate to high intensity (55-75\% $\left.\mathrm{VO}_{2} \mathrm{Max}\right)$. The findings in this study by Gleesom [3] are consistent with our study because the exercise performed was a HIIT with long duration of approximately $120 \mathrm{~min}$. Highintensity exercise could induce an increase in several pro- and anti-inflammatory cytokines level, natural cytokine inhibitor, and chemokines. As a response to exercise, IL-6 is produced locally in the skeletal muscle in higher level than other cytokines, and this induces hepatic glucose output as well as lipolysis [7]. 
The IL-6 is a 184 amino acid protein cytokine produced by many types of cells and expressed in cellular stress such as inflammation, infection, injury site, and cancer [11], [12]. IL-6 is also produced at the site of inflammation and functions as a clinical or biological acute-phase response such as the production of acutephase protein. IL- 6 has stimulation effect on $B$ and $T$ cells, and supports chronic inflammation response [13]. This cytokine is also produced quickly and temporarily as a response toward infection and tissue injury has contribution to body's immunity by giving stimulation to acute-phase response, hematopoiesis, and immune reaction. Although its expression is tightly controlled by the transcription and post-transcription mechanism, unregulated synthesis of IL-6 may cause pathological effect in chronic inflammation and autoimmunity [6]. IL-6 is operated to control how far the response of tissue inflammation. In chronic disease, immune stressor, such chronic intracellular infection, and tumor, the IL-6 function is not only to induce acute phase reaction but also to bring up cellular immunity response toward damaged cells and mucosa humoral response that leads to reoccurrence of infection [13]. Plasma IL-6 will increase when someone do heavy activity [7]. The increment of IL-6 is also caused by sepsis [14] and when trauma occurs [15].

The cause of changes in immune system due to exercise is multifactorial. One of the causes is neuroendocrinological factor such as adrenalin (epinephrine), noradrenalin (norepinephrine), growth hormone, and cortisol [16]. The concentration of these hormones is elevated during exercise and get back to normal soon after the exercise. This process also gives effect to lymphocyte and neutrophil during the recovery phase. The previous study using infused hormone showed that the production of hormone was inhibited by epidural blockage in relation with physical stress that provided contribution to action mechanism [17]. Adrenalin and noradrenalin are in charge in acute exercise effect on lymphocyte change, including functional activity of NK-cells and T-cells. The elevated growth hormone and catecholamine become the mediator of acute effects on neutrophil, while cortisol gives its effects at least $2 \mathrm{~h}$. Therefore, it helps to maintain the lymphopenia only after long duration exercise [18]. Other studies also showed that epinephrine become the mediator effect of exercise on lymphocyte concentration. Therefore, intravenous epinephrine in $1 \mathrm{~h}$ causes lymphocytosis followed with lymphopenia, which is similar to the effects of exercising [19].

Elevated IL-6 secretion inside the body due to the response toward strenuous exercise is caused by elevated of cytokines inhibitor because of antagonize receptor such as IL-1 (IL-1ra) and anti-inflammatory cytokine IL-10 [20]. The quick elevation of IL-6 secretion that is circulating during exercise is mediated by the elevated regulation of transcription and contraction from the skeletal muscle [21]. IL-6 is the only myokine known that can be released from the skeletal muscle to the circulation in the concentration needed [22]. IL-6 is also regulated in adipose tissue and released as the response to exercise [10], [23]. IL-6 secreted from adipose tissue also contributes in systemic elevation of IL-6 in exercise [24].

During recovery after exercise, microstructure damage occurs due to microtrauma in contractile element and the connective tissue shows infiltration of immune cells and cytokines secretion, including IL-6, similar to the inflammatory response toward tissue injury or infection. This effect is mostly delayed or as the metabolic effect of IL-6 during exercise, especially in recovery. The peak circulation concentration from IL-6 released from muscle occurs shortly after acute exercise. Meanwhile, after the peak, the level of IL-6 produced by immune cells may be lower or still high for a long duration to recover the damaged tissue [25].

\section{Conclusions}

The basic exercise performed by new students of Perguruan Pencak Silat Perisai Diri increased IL-6 serum level. This was because the characteristics of the basic exercise in this course were long and strenuous that could cause muscle damage and stimulate the release of more IL-6 to minimize the risk to the body.

\section{Ethical Approval}

This study protocol is already approved by the ethical committee of Public Health Faculty of Universitas Airlangga, Indonesia, in 2020.

\section{Acknowledgments}

Many thanks to the coach of Perguruan Pencak Silat Perisai Diri Tulungrejo, Bojonegoro, and also students from Perguruan Pencak Silat Perisai Diri Tulungrejo, Bojonegoro, without their help this research could not be completed.

\section{References}

1. Pedersen BK, Ullum $H$. NK cell response to physical activity: Possible mechanisms of action. Med Sci Sports Exerc. 1994;26(2):140-6. https://doi. 
org/10.1249/00005768-199402000-00003

PMid:8164530

2. Nieman DC, Pedersen BK. Exercise and immune function. Recent developments. Sports Med. 1999;27(2):73-80. https:// doi.org/10.2165/00007256-199927020-00001

PMid:10091272

3. Gleeson M. Immune function in sport and exercise. J Appl Physiol (1985). 2007;103(2):693-9.

PMid:17303714

4. Williams SL, Strobel NA, Lexis LA, Coombes JS. Antioxidant requirements of endurance athletes: Implications for health. Nutr Rev. 2006;64(3):93-108. https://doi. org/10.1111/j.1753-4887.2006.tb00193.x

PMid: 16572597

5. Ostrowski K, Rohde T, Zacho M, Asp S, Pedersen BK. Evidence that interleukin- 6 is produced in human skeletal muscle during prolonged running. J Physiol. 1998;508(3):949-53. https://doi. org/10.1111/j.1469-7793.1998.949bp.x

PMid:9518745

6. Tanaka T, Narazaki M, Kishimoto T. IL-6 in inflammation, immunity, and disease. Cold Spring Harb Perspect Biol. 2014;6(10):a016295. https://doi.org/10.1101/cshperspect. a016295

PMid:25190079

7. Pedersen BK, Steensberg A, Schjerling P. Exercise and interleukin-6. Curr Opin Hematol. 2001;8(3):137-41. PMid:11303145

8. Suzuki K. Cytokine response to exercise and its modulation Antioxidants (Basel). 2018;7(1):17.

9. Yang $\mathrm{H}$, Antonie DJ, Andersson U, Tracey KJ. The many faces of HMGB1: Molecular structure-functional activity in inflammation, apoptosis, and chemotaxis. J Leukoc Biol. 2013;93(6):865-73. https://doi.org/10.1189/jlb.1212662 PMid:23446148

10. Goh J, Hofmann P, Aw NH, Tan PL, Tschakert G, Mueller A, et al. Concurrent high-intensity aerobic and resistance exercise modulates systemic release of alarmins (HMGB1, S100A8/ A9, HSP70) and inflammatory biomarkers in healthy young men: A pilot study. Transl Med Commun. 2020;5:4. https://doi. org/10.1186/s41231-020-00056-Z

11. Pedersen BK, Steensberg $A$, Schjerling $P$. Exercise and interleukin-6 Curr Opin Hematol. 2001;8(3):137-41. PMid: 11303145

12. Choy E, Rose-John S. Interleukin-6 as a multifunctional regulator: Inflammation, immune response, and fibrosis. J Scleroderma Relat Disord. 2017;2(2):S1-5. https://doi. org/10.5301/jsrd.5000265

13. Gabay C. Interleukin-6 and chronic inflammation. Arthritis Res Ther. 2006;8 Suppl 2:S3.

PMid: 16899107

14. Damas $P$, Ledoux $D$, Nys $M$, Vrindts $Y$, de Groote $D$, Franchimont $\mathrm{P}$, et al. Cytokine serum level during severe sepsis in human IL-6 as a marker of severity. Ann Surg. 1992;215(4):35662. https://doi.org/10.1097/00000658-199204000-00009

\section{PMid:1558416}

15. Schluter B, Konig B, Bergmann U, Muller FE, Konig W, "Interleukin-6, a potential mediator of lethal sepsis after major thermal trauma: Evidence for increased IL- 6 production by peripheral blood mononuclearcells. JTrauma. 1991;31(12):166370. https://doi.org/10.1097/00005373-199112000-00017 PMid: 1749040

16. Steensberg $A$, Toft $A D$, Schjerling $P$, Halkjær-Kristensen $P$ Pedersen BK. Plasma interleukin-6 during strenuous exercise: Roleofepinephrine.AmJPhysiolCellPhysiol.2001;281(3):C10014. https://doi.org/10.1152/ajpcell.2001.281.3.c1001 PMid: 11502577

17. Pedersen BK, Nieman DC. Exercise and immunology: Integration and regulation. Immunol Today. 1998;19(5):204-6. PMid:9613035

18. Pedersen BK, Toft AD. Effects of exercise on lymphocytes and cytokines. Br J Sports Med. 2000;34(4):246-51. PMid:10953894

19. Tvede N, Kappel M, Klarlund K, Duhn S, Halkjaer-Kristensen $\mathrm{J}$, Kjaer M, et al. Evidence that the effect of bicycle exercise on blood mononuclear cell proliferative responses and subsets is mediated by epinephrine. Int J Sports Med. 1994;15(2):100-4. https://doi.org/10.1055/s-2007-1021028

PMid:8157368

20. Steensberg A, Fischer CP, Keller C, Møller K, Pedersen BK IL-6 enhances plasma IL-1ra, IL-10, and cortisol in humans. Am J Physiol Endocrinol Metab. 2003;285:E433-7. https://doi. org/10.1152/ajpendo.00074.2003 PMid: 12857678

21. Chan MH, McGee SL, Watt MJ, Hargreaves M, Febbraio MA. Altering dietary nutrient intake that reduces glycogen content leads to phosphorylation of nuclear p38 MAP kinase in human skeletal muscle: Association with IL-6 gene transcription during contraction. FASEB J. 2004;18(14):1785-7. https://doi. org/10.1096/fj.03-1039fje

PMid: 15345683

22. Keller C, Steensberg A, Pilegaard H, Osada T, Saltin B, Pedersen BK, et al. Transcriptional activation of the IL-6 gene in human contracting skeletal muscle: Influence of muscle glycogen content. FASEB J. 2001;15(14):2748-50. https://doi. org/10.1096/fj.01-0507fje

\section{PMid:11687509}

23. Pedersen BK, Hoffman-Goetz L. Exercise and the immune system: Regulation, integration, and adaptation. Physiol Rev. 2000;80(3):1055-81

PMid: 10893431

24. Lyngsø D, Simonsen L, Bulow J. Interleukin- 6 production in human subcutaneous abdominal adipose tissue: The effect of exercise. J Physiol. 2002;543(1):373-8. https://doi.org/10.1113/ jphysiol.2002.019380 PMid: 12181307

25. Fischer CP. Interleukin- 6 in acute exercise and training: What is the biological relevance? Exerc Immunol Rev. 2006;12:6-33. PMid:17201070 